\title{
A western gray whale mitigation and monitoring program for a 3-D seismic survey, Sakhalin Island, Russia
}

\author{
S. R. Johnson • W. J. Richardson • S. B. Yazvenko • \\ S. A. Blokhin • G. Gailey • M. R. Jenkerson • \\ S. K. Meier • H. R. Melton • M. W. Newcomer • \\ A. S. Perlov • S. A. Rutenko $\cdot$ B. Würsig • \\ C. R. Martin • D. E. Egging
}

Received: 20 April 2006 / Accepted: 29 March 2007 / Published online: 27 July 2007

(C) Springer Science + Business Media B.V. 2007

\begin{abstract}
The introduction of anthropogenic sounds into the marine environment can impact some marine mammals. Impacts can be greatly reduced if appropriate mitigation measures and monitoring are implemented. This paper concerns such measures undertaken by Exxon Neftegas Limited, as operator of the Sakhalin-1 Consortium, during the Odoptu 3-D seismic survey conducted during 17 August-9 Sep-
\end{abstract}

M. W. Newcomer is deceased.

S. R. Johnson $(\bowtie) \cdot S$. B. Yazvenko $\cdot$ S. K. Meier

LGL Limited, environmental research associates,

9768 Second Street,

Sidney, BC V8L 3Y8, Canada

e-mail: srj@lgl.com

W. J. Richardson

LGL Limited, environmental research associates,

POB 280, 22 Fisher Street,

King City, ON L7B 1A6, Canada

S. A. Blokhin · A. S. Perlov

Pacific Research Center for Fisheries and Oceanography

(TINRO-Center), 4 Shevchenko Alley,

Vladivostok 690950, Russia

G. Gailey $\cdot$ B. Würsig

Texas A\&M University at Galveston,

4700 Avenue U-Building 303,

Galveston, TX 77551-5923, USA

M. R. Jenkerson $\cdot$ H. R. Melton

ExxonMobil Upstream Research Company,

P.O. Box 2189, Houston, TX 77252-2189, USA tember 2001. The key environmental issue was protection of the critically endangered western gray whale (Eschrichtius robustus), which feeds in summer and fall primarily in the Piltun feeding area off northeast Sakhalin Island. Existing mitigation and monitoring practices for seismic surveys in other jurisdictions were evaluated to identify best practices for reducing impacts on feeding activity by western

M. W. Newcomer

22371 Hartman Drive,

Los Altos, CA 94024, USA

S. A. Rutenko

V.I. Il'icev Pacific Oceanological Institute,

Far East Branch of Russian Academy of Science,

43 Baltyskaya Street,

Vladivostok 690068, Russia

C. R. Martin · D. E. Egging

ExxonMobil Development Company,

P.O. Box 4876, Houston,

TX 77210-4876, USA

Present address:

M. R. Jenkerson

ExxonMobil Exploration Company,

P.O. Box 4778, Houston, TX 77210-4778, USA

Present address:

C. R. Martin

Esso Exploration and Production Chad Inc.,

Kome, Chad 
gray whales. Two buffer zones were established to protect whales from physical injury or undue disturbance during feeding. A $1 \mathrm{~km}$ buffer protected all whales from exposure to levels of sound energy potentially capable of producing physical injury. A 4-5 km buffer was established to avoid displacing western gray whales from feeding areas. Trained Marine Mammal Observers (MMOs) on the seismic ship Nordic Explorer had the authority to shut down the air guns if whales were sighted within these buffers.

Additional mitigation measures were also incorporated: Temporal mitigation was provided by rescheduling the program from June-August to August-September to avoid interference with spring arrival of migrating gray whales. The survey area was reduced by $19 \%$ to avoid certain waters $<20 \mathrm{~m}$ deep where feeding whales concentrated and where seismic acquisition was a lower priority. The number of air guns and total volume of the air guns were reduced by about half (from 28 to 14 air guns and from 3,390 in ${ }^{3}$ to $1,640 \mathrm{in}^{3}$ ) relative to initial plans. "Ramp-up" (=“soft-start") procedures were implemented.

Monitoring activities were conducted as needed to implement some mitigation measures, and to assess residual impacts. Aerial and vessel-based surveys determined the distribution of whales before, during and after the seismic survey. Daily aerial reconnaissance helped verify whale-free areas and select the sequence of seismic lines to be surveyed. A scout vessel with MMOs aboard was positioned $4 \mathrm{~km}$ shoreward of the active seismic vessel to provide better visual coverage of the $4-5 \mathrm{~km}$ buffer and to help define the inshore edge of the $4-5 \mathrm{~km}$ buffer. A second scout vessel remained near the seismic vessel. Shore-based observers determined whale numbers, distribution, and behavior during and after the seismic survey. Acoustic monitoring documented received sound levels near and in the main whale feeding area.

Statistical analyses of aerial survey data indicated that about 5-10 gray whales moved away from waters near (inshore of) the seismic survey during seismic operations. They shifted into the core gray whale feeding area farther south, and the proportion of gray whales observed feeding did not change over the study period.

Five shutdowns of the air guns were invoked for gray whales seen within or near the buffer. A previously unknown gray whale feeding area (the Offshore feeding area) was discovered south and offshore from the nearshore Piltun feeding area. The Offshore area has subsequently been shown to be used by feeding gray whales during several years when no anthropogenic activity occurred near the Piltun feeding area.

Shore-based counts indicated that whales continued to feed inshore of the Odoptu block throughout the seismic survey, with no significant correlation between gray whale abundance and seismic activity. Average values of most behavioral parameters were similar to those without seismic surveys. Univariate analysis showed no correlation between seismic sound levels and any behavioral parameter. Multiple regression analyses indicated that, after allowance for environmental covariates, 5 of 11 behavioral parameters were statistically correlated with estimated seismic surveyrelated variables; 6 of 11 behavioral parameters were not statistically correlated with seismic survey-related variables. Behavioral parameters that were correlated with seismic variables were transient and within the range of variation attributable to environmental effects.

Acoustic monitoring determined that the $4-5 \mathrm{~km}$ buffer zone, in conjunction with reduction of the air gun array to 14 guns and $1,640 \mathrm{in}^{3}$, was effective in limiting sound exposure. Within the Piltun feeding area, these mitigation measures were designed to insure that western gray whales were not exposed to received levels exceeding the $163 \mathrm{~dB}$ re $1 \mu \mathrm{Pa}$ (rms) threshold.

This was among the most complex and intensive mitigation programs ever conducted for any marine mammal. It provided valuable new information about underwater sounds and gray whale responses during a nearshore seismic program that will be useful in planning future work. Overall, the efforts in 2001 were successful in reducing impacts to levels tolerable by western gray whales. Research in 2002-2005 suggested no biologically significant or populationlevel impacts of the 2001 seismic survey.

Keywords Seismic survey · Mitigation · Monitoring · Western gray whale Eschrichtius robustus . Sakhalin Island $\cdot$ Okhotsk Sea $\cdot$ Russia

\section{Introduction}

Anthropogenic underwater noise and its potential impacts on marine mammals have been the subject 
of considerable concern and research in recent years (e.g., NRC 1994, 2000, 2003, 2005; Moore and Clarke 2002; Gordon et al. 2004; Richardson et al. 1995). Exxon Neftegas Limited (ENL) and partners in the Sakhalin-1 Consortium are developing oil and gas reserves on the nearshore continental shelf off northeast Sakhalin Island, Russia. That area is near feeding areas used in summer and autumn by the Western North Pacific population of the gray whale, Eschrichtius robustus. Western gray whales are listed as endangered in the Russian Red Book (Anonymous 2001) and critically endangered by IUCN-The World Conservation Union (Hilton-Taylor 2000). In addition, starting in 1999 some individual western gray whales were reported to be emaciated (Weller et al. 1999, 2001, 2002b). In 2001, this small population of whales was estimated to include about 100 individuals, of which less than 50 were reproductively active adults (Hilton-Taylor 2000). More recent studies suggest the population may consist of at least 122 non-calf individuals (Cooke et al. 2006).

DalMorNefteGeofizika (DMNG), on behalf of the Sakhalin-1 Consortium, conducted a 3-D seismic survey of the Odoptu Block Seismic Area within the Odoptu License Area off northeastern Sakhalin Island from 17 August to 9 September 2001 (Fig. 1). The energy source for the seismic survey was an array of air guns towed behind the vessel Nordic Explorer. The seismic survey was preceded by an Environmental Impact Assessment (EIA), which determined that the key environmental issue was protection of the western gray whale.

Detailed behavior studies conducted near Eastern North Pacific gray whales exposed to air gun pulses (Malme and Miles 1985; Malme et al. 1983, 1984, 1988; Würsig et al. 1986) provided the best information available on the potential responses of gray whales to seismic surveys. These studies of feeding gray whales in the Bering Sea and migrating gray whales off California suggested that $\mathrm{ca} 10 \%$ of gray whales would probably behaviorally respond by moving away from the seismic vessel if received levels of air gun sound were $\geq 163 \mathrm{~dB}$ re $1 \mu \mathrm{Pa}(\mathrm{rms})$, as measured in the water column.

A western gray whale mitigation and monitoring program was designed and implemented for the Odoptu seismic surveys. This program took account of the behavioral response data from eastern gray whales, along with reviews of all available information and recommendations for mitigating potential impacts of seismic sounds on western gray whales and on other cetaceans in other jurisdictions.

In the two years preceding the 2001 seismic survey, feeding western gray whales were predominantly localized in the near-shore marine area adjacent to Piltun Bay along the northeast Sakhalin coast (Sobolevsky 2000, 2001). During these years, $>95 \%$ of all gray whale observations in this area were located shoreward of the $20 \mathrm{~m}$ water depth contour (Fig. 2). Because of this known localized distribution of whales near the Odoptu seismic survey area, it was possible to design a mitigation and monitoring strategy to reduce potential impacts on the feeding activity of the whales.

This paper, and accompanying papers in this volume (Yazvenko et al. 2007a,b; Meier et al. 2007; Gailey et al. 2007; Rutenko et al. 2007), describe the objectives, methods, rationale, and effectiveness of the mitigation and monitoring strategies adopted during the Odoptu seismic survey, and summarize important results of the various components of the monitoring program.

\section{Mitigation and monitoring goals}

Exploration of the Odoptu license area off northeast Sakhalin Island involved a 3-D seismic survey during the 2001 open water season. The Odoptu license area is situated (mainly) offshore from the Piltun feeding area used by western gray whales. However, the inshore edge of the Odoptu license area overlaps with the offshore edge of the Piltun feeding area (Fig. 1). The primary goal for the mitigation and monitoring programs was to reduce impacts of the seismic survey on the feeding activity of western gray whales while allowing the seismic survey to proceed. These measures would also reduce any possibility that seismic sound pulses might injure whales at close range.

\section{Development of a mitigation strategy}

Guidelines for mitigation measures

Given the potential sensitivity of the western gray whale population and known behavioral responses of the eastern population of gray whales to seismic survey sounds (Malme et al. 1983, 1984, 1986, 1988), all 
Fig. 1 Intensive and extensive aerial survey grids, and subdivisions of the Odoptu Block Seismic Area relative to the $20 \mathrm{~m}$ isobath offshore from Piltun Bay, Sakhalin Island, Russia, 2001.

The band dividing area $\mathrm{A}$ and area $B$ is $4-5 \mathrm{~km}$ seaward of the outer boundary of the feeding area (see text). The dashed perimeter around the Odoptu block represents the original seismic survey area before it was reduced in size by $19 \%$

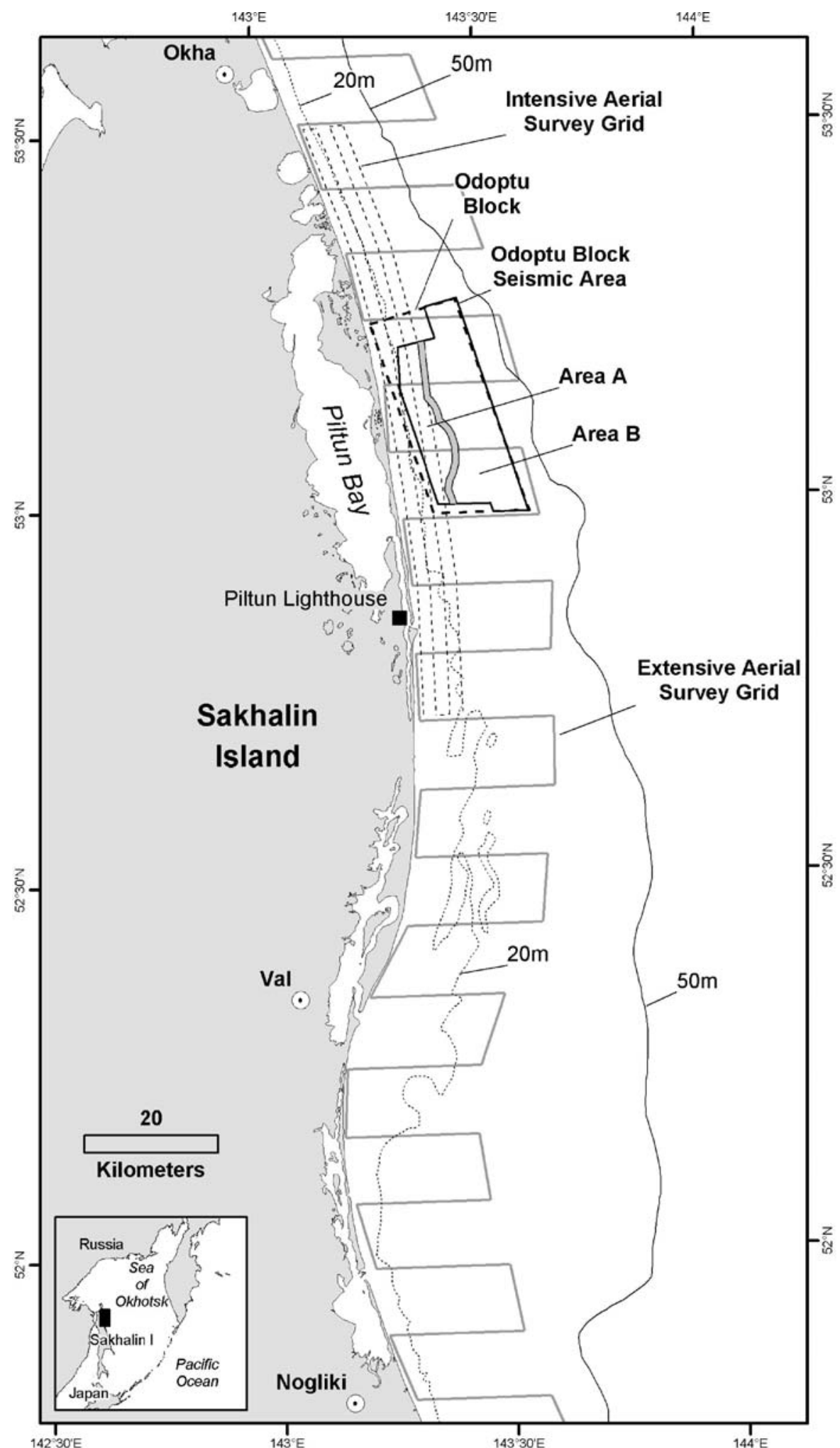




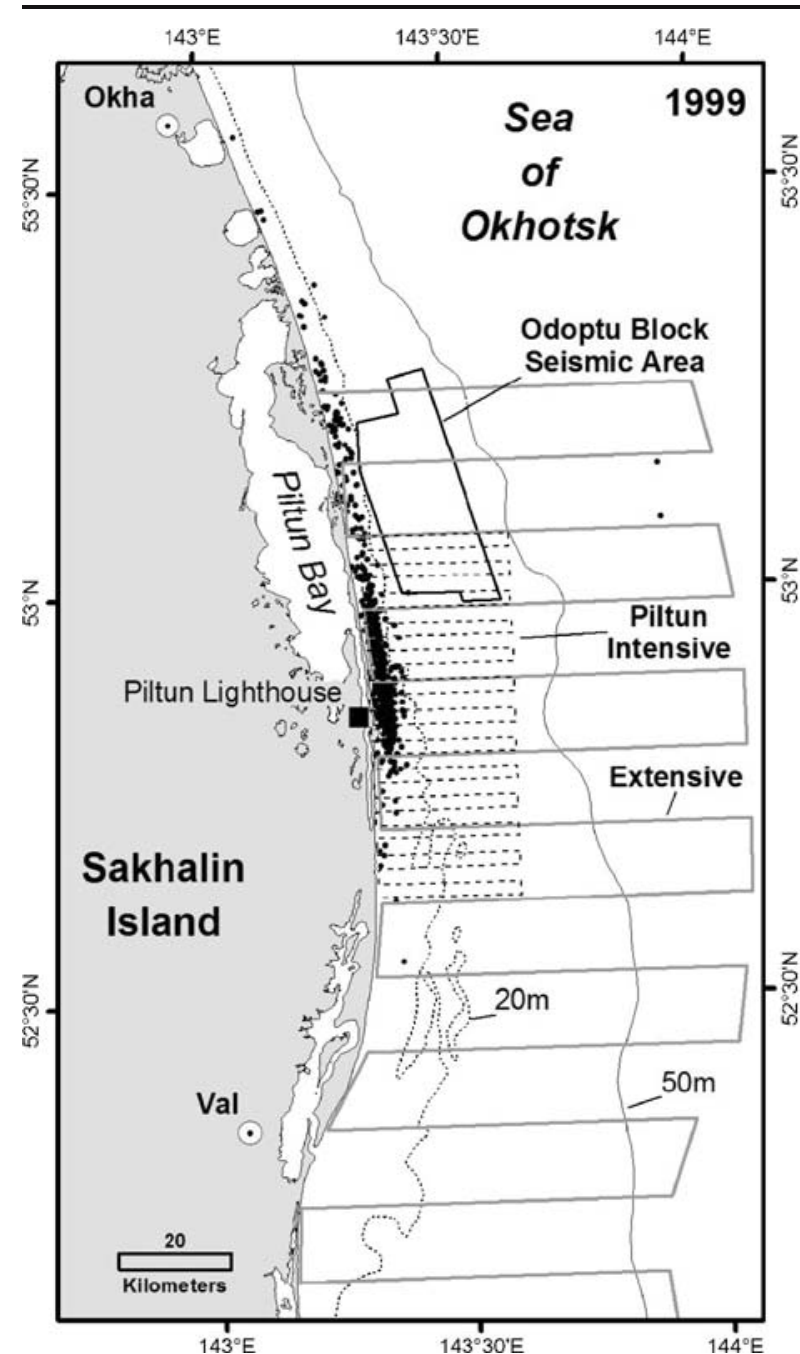

Fig. 2 Distribution of western gray whales in the Piltun feeding area, Sakhalin Island, Russia, determined from systematic aerial (helicopter) surveys conducted during 1999-2000. Survey effort was similar in both years: 13 surveys during JulyNovember 1999 (Sobolevsky 2000) and 14 surveys during

known mitigation measures were considered and, where possible or practical, were adopted and implemented.

Three sets of published mitigation guidelines/ recommendations were reviewed and considered for implementation in the Odoptu area, as follows:

- Guidelines/recommendations of the Joint Nature Conservation Committee (JNCC) of the United Kingdom (Stone 1998, 2000).

- Guidelines/recommendations of the Southern California High Energy Seismic Survey (HESS) Team (HESS 1999), as described in Quan and Calambokidis (1999).



June-November 2000 (Sobolevsky 2001). An additional coastal transect, located approximately $2 \mathrm{~km}$ seaward of and parallel to the Sakhalin coastline from approximately $52^{\circ} 40^{\prime} \mathrm{N}$ to $53^{\circ} 30^{\prime} \mathrm{N}$, was also surveyed during each aerial survey in 1999 and 2000

- Guidelines/Recommendations of Environment Australia (Environment Australia 2001) and the Australian Petroleum Production and Exploration Association (APPEA), as described in McCauley et al. (2000a,b).

Seismic surveys in the Alaskan Beaufort Sea had also been subject to regulatory action, and have included extensive monitoring and mitigation requirements. No standardized guidelines or requirements have been published for that area, but requirements concerning both cetaceans and pinnipeds have evolved (e.g., NMFS 1999, 2000). The then-existing 
Alaskan Beaufort Sea requirements were also reviewed and considered during the development of the Odoptu mitigation program. More recent seismic mitigation measures/recommendations for large cetaceans were not available in 2001 and thus were not considered.

Evaluation and adoption of mitigation measures and monitoring studies

After reviewing the above guidelines and recommendations and other relevant scientific literature (e.g., Malme and Miles 1985; section 11.10 in Richardson et al. 1995; Malme et al. 1986, 1988), a series of mitigation measures were considered for adoption. Mitigation measures were designed primarily to reduce impacts on the feeding activity of the western gray whales, but they also reduced impacts on other species of marine mammals.

\section{Establishment of buffer distances}

A key concept in the Odoptu seismic mitigation strategy was the establishment of buffer distances to protect the critically endangered western gray whale and other whales, including killer whales Orcinus orca, but not other porpoises or dolphins. The establishment of buffer zones or distances during seismic surveys is recommended by JNCC, the Southern California HESS team (HESS 1999), and by the Australian government. The objective is to avoid or reduce exposure of marine mammals to noise from air guns operating at distances closer than the buffer distance.

A "safety buffer" distance was established to avoid any potential for physical injury; this was applied to all whales, not just gray whales, present in the Odoptu study area during seismic survey operations. For western gray whales, a larger "feeding buffer" distance was established to allow them to remain in the Piltun feeding area with little interruption of feeding.

Safety buffer: Cetaceans may suffer some hearing impairment if exposed to very high levels of impulsive noise, such as seismic pulses. The received level necessary to cause temporary or (perhaps) permanent hearing impairment in a baleen whale is unknown. However, a received level of 180 decibels relative to one micro-Pascal, calculated on a root mean square basis over the duration of the sound pulse (i.e., $180 \mathrm{~dB}$ re $1 \mu \mathrm{Pa} \mathrm{rms}$ ), is often cited as a received level below which cetacean hearing is unlikely to be impaired by pulsed sounds (HESS 1999; NMFS 1999, 2000). The 28 air guns planned for use in the full Odoptu seismic source had a combined volume of 3,090 $\mathrm{in}^{3}$. Based on pre-seismic modeling of the air gun array and noise propagation characteristics, the received levels from this array were estimated to attenuate to a level $\leq 180 \mathrm{~dB}$ re $1 \mu \mathrm{Pa}$ (rms) at a distance of about $880 \mathrm{~m}$ from the array. For reasons described below, however, a reduced air gun volume of 1,640 in ${ }^{3}$ (14 air guns) was used for the Odoptu survey. The distance at which a seismic pulse from the reduced-volume array would attenuate to a level $\leq 180 \mathrm{~dB}$ re $1 \mu \mathrm{Pa}$ (rms) was about $565 \mathrm{~m}$. Nevertheless, throughout the seismic survey, a safety buffer distance of $1 \mathrm{~km}$ was adopted for all whales.

Feeding buffer: The behavior of whales can be affected at lower received sound levels than those that might cause temporary hearing loss or physical injury (Richardson et al. 1995). Würsig et al. (1999) reported that noise associated with a 1997 seismic survey near the Piltun feeding area may have caused changes in western gray whale behavior. These suspected behavioral changes included alterations in swimming speed and direction, distance traveled, and surface-respiration-dive characteristics (blow interval) during periods when seismic surveys were being conducted. It was unclear, however, if these effects were related to seismic operations, because some changes were not consistent with changes noted in previous studies of whales exposed to air gun noise (Würsig et al. 1999), i.e., the blow rate in 1997 showed a decrease rather than the expected increase. As noted earlier, the behavior studies conducted near eastern gray whales in the Bering Sea and off California exposed to air gun pulses (Malme and Miles 1985; Malme et al. 1983, 1984, 1986, 1988) indicated that (1) ca $10 \%$ of gray whales moved away from the air gun(s) when received levels of air gun sound were $\geq 163 \mathrm{~dB}$ re $1 \mu \mathrm{Pa}$ (rms), and (2) the sound would, in the Bering Sea, attenuate to $<163 \mathrm{~dB}$ re $1 \mu \mathrm{Pa}(\mathrm{rms})$ by 4 to $5 \mathrm{~km}$ from the seismic vessel. It is notable that, in the Bering Sea, most displaced feeding gray whales returned to their original locations and 
resumed feeding within $1 \mathrm{hr}$ after the seismic source was shut down (Malme et al. 1986). This 4-5 km range identified in the Bering Sea study was used for initial planning of the Odoptu mitigation and monitoring program. The specific distance would, however, depend on the particular configuration of air guns and on sitespecific sound propagation conditions (Urick 1982; Richardson et al. 1995).

Given their critically endangered status, western gray whales feeding near the Odoptu Block could not be the subject of experimentation to determine the maximum sound level tolerated before feeding activity was affected. Rather, the objective in 2001 was to ensure that the seismic survey did not cause gray whales to stop feeding. To achieve that objective, the project was planned and conducted so sound levels near feeding western gray whales would not exceed the $163 \mathrm{~dB}$ re $1 \mu \mathrm{Pa}$ (rms) level determined by Malme et al. (1986, 1988). To allow for the anticipated effects of air gun source configuration and local sound propagation conditions, a calibration study was conducted prior to the seismic survey to better define sound attenuation in the study area (Rutenko et al. 2007). The calibration study indicated that, to limit noise exposure to $<163 \mathrm{~dB}$ re $1 \mu \mathrm{Pa}$ (rms) while allowing seismic operations at distances as close as $4 \mathrm{~km}$ from feeding gray whales, the air gun array would need to operate at approximately half volume (see "Air gun array configuration and aspect dependency" below; Borisov et al. 2002; Rutenko et al. 2007). This reduction in the number and total volume of air guns resulted in reduction in the quality of the geophysical data, but within tolerable limits.

Having adopted $163 \mathrm{~dB}$ re $1 \mu \mathrm{Pa}(\mathrm{rms})$ received level as an upper limit for noise exposure, it was necessary to determine how to manage the mitigation and monitoring program to ensure minimal impact on the feeding activity of western gray whales. The $20 \mathrm{~m}$ isobath defined the seaward edge of the known distribution of virtually all feeding gray whales in the Piltun area (Figs. 2 and 3). Hence, sound levels within the feeding area would not exceed $163 \mathrm{~dB}$ re $1 \mu \mathrm{Pa}$ (rms) when operations with the reduced air gun array were conducted $\geq 4 \mathrm{~km}$ seaward of the $20 \mathrm{~m}$ isobath. However, parts of the Odoptu block of interest to ENL were $<4 \mathrm{~km}$ seaward of the $20 \mathrm{~m}$ isobath, and additional provisions were required there (see "Stratification of the study area", below).
At the instruction of the Russian agency "Sakhalin Basin Office on the Protection and Regeneration of Fisheries Resources and Fisheries Management" (SakRybVod), both the $4 \mathrm{~km}$ feeding buffer and the $1 \mathrm{~km}$ safety buffer were arbitrarily expanded to $5 \mathrm{~km}$ on 22 August 2001 after 5 days of operation. As authorized by SakRybVod, the safety buffer was expanded to $3 \mathrm{~km}$ during 23 August-6 September 2001. The $4 \mathrm{~km}$ feeding buffer for endangered whales and the $1 \mathrm{~km}$ safety buffer for all whales were reimplemented on 7 September, in accordance with instructions from the Russian Ministry of Natural Resources (MNR). The seismic survey ended at 03:30 local Sakhalin time, 9 September 2001.

Stratification of the study area: Since the western gray whales near the Odoptu area were known to feed mainly in waters inshore from the $20 \mathrm{~m}$ isobath (Figs. 2 and 3), the zone designated for seismic activity was divided into two sub-areas, areas A and $\mathrm{B}$, to help maintain buffer distances.

Area A was the part of the Odoptu seismic block within 4 or $5 \mathrm{~km}$ seaward from the $20 \mathrm{~m}$ isobath. With air guns operating at the seaward edge of area A, sound from the seismic survey would have attenuated below $163 \mathrm{~dB}$ re $1 \mu \mathrm{Pa}(\mathrm{rms})$ at the seaward edge of the feeding area (20 m contour). As recommended in the JNCC, HESS, and Australian guidelines, seismic surveys closest to the feeding whales (e.g., in area A, potentially $<4 \mathrm{~km}$ from whales) were restricted to daylight hours and periods of good visibility. With the help of aerial and vessel-based surveillance (see "Aerial surveys" and "Vessel-based marine mammal observer program", below), shooting of seismic lines in area A was timed and conducted to avoid operations within 4 or $5 \mathrm{~km}$ from all observed western gray whales.

Area B was the area within the Odoptu seismic block boundary that was $\geq 4-5 \mathrm{~km}$ seaward of the $20 \mathrm{~m}$ isobath (Fig. 1). During seismic operations in area B, sound levels within the Piltun feeding area should always be below the target threshold of $163 \mathrm{~dB}$ re $1 \mu \mathrm{Pa}$ (rms). Systematic aerial and vesselbased surveillance was also conducted during the seismic survey in area $B$. The same shutdown distances were maintained during seismic acquisition in area B as for area A. However, because very few gray whales had been documented in Area B in prior 
Fig. 3 Distribution of western gray whale sightings in 2001 recorded during aerial (fixed-wing aircraft) surveys (dots) and vessel-based surveys (squares) in the Piltun and Offshore feeding areas. The offshore feeding area was discovered on $10 \mathrm{Sep}$ tember 2001 (Maminov and Yakovlev 2002); surveys in the Offshore feeding area were over a shorter duration (11 September-19 November 2001) than those in the Piltun feeding area

(19 July-19 November 2001)




years (Sobolevsky 2000, 2001), seismic surveys in area B were not restricted to daylight hours or to periods of good visibility. Night-vision binoculars were used during night operations in area $\mathrm{B}$, although it was anticipated that their effectiveness would be limited.

\section{Seasonal and geographic considerations}

The JNCC, HESS and Australian seismic survey guidelines recommend consideration of both seasonal and geographic restrictions to reduce impacts of seismic surveys on marine mammals. For the Odoptu seismic survey, two measures pertaining to timing of the seismic surveys and impacts on gray whales were evaluated:

- Conduct seismic exploration during winter (December through May) when gray whales are absent from the area.

- If the above measure is not possible, conduct seismic operations when the fewest gray whales are present (early spring or late fall).

Extensive moving ice pack is present during December through May, and this precluded scheduling the Odoptu seismic survey during winter or early spring. On-ice seismic survey methods require thick shore-fast ice, which does not occur in this area. Thus, seismic surveys could only be safely accomplished in ice-free open water.

The option of delaying the seismic surveys originally planned for June and July until October and November was considered. However, analysis of weather data and a review of safety and operational reports from previous seismic surveys conducted on the northeast Sakhalin shelf in late fall indicated that severe storms starting in mid-October precluded the safe conduct of the seismic survey during this period.

Nevertheless, during the planning phase, the seismic survey was rescheduled to the mid-August through mid-October period. This avoided the spring through early summer period when gray whales, some with new-borne calves, return to the Piltun feeding area and commence feeding. However, this delay involved judicious trade-offs. It necessitated expanding the survey period from 6-8 weeks that would have sufficed in June and July to $8-10$ weeks in August through October because of the probability of delays caused by late-summer and fall storms. Also, the higher probability of encountering western gray whales in Area A of the Odoptu seismic block during late summer (Meier et al. 2007) was anticipated to necessitate more shut downs and delays to the program. The revised start date for the seismic survey was determined by back-dating 10 weeks from 15 October 2001, which was the date beyond which seismic surveys could not be conducted safely.

Additionally, during the planning phase, the size of the overall seismic survey area was reduced by approximately $19 \%$, and area A was reduced by $43 \%$ (Fig. 1). All areas of the seismic survey block in waters shallower than $20 \mathrm{~m}$ were eliminated. Therefore no seismic surveys were conducted within that portion of Area A where western gray whales were known to aggregate. With these reductions, the seismic survey was completed on 9 September 2001, well before the estimated 15 October 2001 completion date. This further reduced the period of exposure of the western gray whales to seismic pulses.

\section{Adaptable seismic survey line shooting sequence}

In addition to the above-mentioned seasonal and geographic considerations, it was considered prudent to maintain flexibility in the shooting sequence of individual seismic lines within the Odoptu seismic survey block. If aerial or vessel surveillance indicated that gray whales were present in feeding areas near the Odoptu block, i.e., in area A, seismic lines in area B were chosen for shooting. In general, seismic lines in area B, i.e., lines farthest from the Piltun feeding area, were surveyed earliest. This approach may also have allowed the gray whales to habituate to the more distant seismic pulses.

\section{Ramp-up or soft-start}

The ramp-up (= soft-start) procedures recommended by the JNCC, HESS, and Australian guidelines were fully adopted for the Odoptu seismic survey. The seismic operator increased the source level of the air guns slowly (in $\sim 6 \mathrm{~dB}$ increments) over a period of $\sim 20$ min each time seismic shooting began if the previous shut-down period had been substantial, i.e. >15 min. Eastern gray whales showed avoidance responses when a single air gun began firing (Malme 
et al. 1988). Thus, the ramp-up procedure was anticipated to encourage any unseen gray whales (and perhaps other species) close to the ship to move away before the received sound level became high enough to be harmful.

\section{Air gun array configuration and aspect dependency}

The JNCC, HESS and Australian guidelines all discuss the desirability of avoiding unnecessarily strong energy sources, minimizing the proportion of the energy that propagates horizontally, and minimizing the amount of energy at frequencies above those useful for geophysical surveys. Acoustic modeling conducted prior to the Odoptu seismic survey indicated that there would likely be very little "aspect dependence" of received sound levels at various locations around the seismic vessel, contrary to the aspect dependence noted elsewhere during some other shallow-water seismic surveys (Richardson et al. 1995, pp. 138-139). The Odoptu seismic survey was designed to follow lines parallel to the coast, so feeding whales inshore of the survey lines would be at broadside aspect when the ship was at its closest point of approach.

An acoustic calibration study was conducted prior to the seismic survey to investigate possible "aspect dependence". The calibration study showed that received sound levels broadside to the vessel were approximately $6 \mathrm{~dB}$ higher than levels at corresponding distances directly ahead of the vessel (Borisov et al. 2002; Rutenko et al. 2007). As a result, to mitigate possible high received levels near the gray whales, the entire Odoptu seismic survey was conducted with the air gun array operating at approximately half volume (14 air guns totaling 1,640 $\mathrm{in}^{3}$ ).

\section{Seismic shut-down}

The HESS and Australian guidelines discuss the rationale and procedures for suspending seismic surveys ("shut-downs") when marine mammals are detected near the operating seismic source. The operational plans for the Odoptu seismic survey called for the number of operating air guns to be reduced if a whale came within the safety buffer distance (for all whales) or feeding buffer distance (for endangered whales) of the operating seismic vessel. In practice, if a whale was sighted within applicable buffer distances, all air guns were shut down. The MMOs aboard the Nordic Explorer were given responsibility and authority to shut down the air guns when a whale was sighted within the buffer distance. If a shutdown occurred, operations were allowed to resume 30 minutes after the whale left the buffer zone.

\section{Development of a monitoring strategy}

Monitoring was an integral part of the overall mitigation strategy for the Odoptu seismic survey. The monitoring studies provided scientists and managers with the near real-time information necessary to successfully implement mitigation measures during the course of the seismic survey. The same information provided a basis for making adjustments to the mitigation program as new information about sounds and whale responses became available during the course of the seismic survey - an adaptive management approach (Holling 1978). In addition, the monitoring studies were designed to provide information of lasting scientific value about the reactions of gray whales to the operation.

The monitoring studies consisted of four separate components-aerial monitoring (Yazvenko et al. 2002, 2007a,b), vessel-based monitoring (Meier et al. 2002, 2007), shore-based counts and behavior monitoring (Würsig et al. 2002; Gailey et al. 2007), and acoustic monitoring (Borisov et al. 2002; Rutenko et al. 2007). The following sections summarize the goals and objectives of the Odoptu monitoring studies, and their linkages to the mitigation program.

\section{Aerial surveys}

A program of replicated aerial surveys was adopted to determine the local and regional distribution and abundance of western gray whales and other whales before, during, and after the Odoptu seismic survey. During the seismic survey, the Odoptu block and adjacent areas were surveyed one or more times per day when weather allowed. This information about the whales, especially that recorded daily before and during the seismic survey, was critical to the 
successful implementation of mitigation measures. Comparable aerial surveys of the Offshore feeding area (Fig. 3) were not conducted in 2001 because this feeding area was not discovered until after the 2001 seismic survey had ended (Maminov and Yakovlev 2002; Blokhin et al. 2002; Yazvenko et al. 2002).

The specific objectives of the Odoptu aerial monitoring program in 2001 (Yazvenko et al. 2002, 2007a,b) were as follows:

- Determine the locations of gray and other whales in relation to seismic lines scheduled to be surveyed within the next 2-4 h. These pre-seismic aerial surveys used near real-time VHF radio and satellite phone communication among the survey aircraft, the base of operations in nearby Nogliki, and the seismic ship Nordic Explorer to plan seismic survey activity, particularly in area A. They also provided the information necessary for the seismic ship to avoid western gray whales and other endangered whales within or approaching the buffers around seismic lines scheduled to be surveyed within the next few hours.

- Determine on a near real-time basis whether (and by how much) the distribution and feeding activity of gray whales changed during the seismic survey period and whether whales moved seaward or to the north or south away from the main feeding area. In subsequent statistical analyses, results of the aerial surveys were used to assess (1) whether any detectable changes in western gray whale distribution or feeding activity occurred during the seismic survey period relative to the pre- and/or post-seismic periods, (2) whether detectable changes could be explained by environmental variables and/or seismic-related activities, and (3) whether the whales stayed in the feeding areas used in the past.

- Conduct reconnaissance over-flights in other areas adjacent to Sakhalin Island in an attempt to find other western gray whale feeding aggregations.

The survey area included coastal areas occupied by all marine mammals (cetaceans and pinnipeds) potentially present in the study area, but the surveys were focused on western gray whales. An extensive survey grid sampled a broad coastal area, and an intensive survey grid covered all nearshore habitats in the areas immediately adjacent to the Piltun feeding area (Fig. 1).
The extensive survey grid covered offshore areas where few or no gray whales had been reported during past surveys, but also included nearshore portions of the study area where gray whales were known to aggregate. It was important to sample this entire area to determine whether some whales were displaced during the seismic surveys to waters other than those where they normally occur. Each survey of the extensive grid covered $\sim 300 \mathrm{~km}$ of coast extending from $51^{\circ} \mathrm{N}$ in the south to $54^{\circ} \mathrm{N}$ in the north, and sampled waters out to $20 \mathrm{~km}$ offshore. The extensive grid was surveyed nine times from 18 July to 19 November 2001.

The intensive aerial survey grid covered specific coastal areas, including waters $<20 \mathrm{~m}$ deep, near and adjacent to the Odoptu seismic block and adjacent to Piltun Lagoon, where the gray whales were known to aggregate to feed. Four transects spaced $2 \mathrm{~km}$ apart were established parallel to shore (2 transects in waters $<20 \mathrm{~m}$ deep and two transects outside the $20-\mathrm{m}$ isobath), covering $\sim 90 \mathrm{~km}$ of coastline from $52^{\circ} 43^{\prime} \mathrm{N}$ to $53^{\circ} 31^{\prime} \mathrm{N}$, and extending seaward beyond the known feeding grounds of gray whales adjacent to Piltun Bay (Fig. 1). Where feasible, coastal surveys included known aggregation areas of pinnipeds, including haulout sites. Weather permitting, the intensive grid was surveyed one to two times per day on most days from 29 July to 27 October 2001, for a total of 90 complete or near-complete intensive surveys.

In mid-September 2001, the aerial survey program was also extended to an additional sampling areathe Offshore survey grid (Fig. 3). A previously unknown gray whale feeding area was discovered in offshore waters on 10 September 2001 by the vesselbased survey team (Maminov and Yakovlev 2002; Meier et al. 2002). Fragmentary data from prior years, and more extensive data from 2002-2005, show that this offshore feeding area has in fact been used by feeding gray whales at some times during years before and after 2001 when there was no nearshore seismic survey (Sobolevsky 2000; Miyashita et al. 2001; Maminov and Yakovlev 2002; Yazvenko et al. 2002; Meier et al. 2002, 2007; Blokhin et al. 2006).

Aerial survey procedures followed those recommended by the HESS team (HESS 1999). The intensity of surveys in this study, however, exceeded recommendations of HESS (Yazvenko et al. 2007a,b).

Aerial observers were biologists experienced in conducting aerial surveys and identifying and recording 
information about all marine mammal species likely to be present in the area. Besides collecting all standard types of aerial survey data, the observers recorded sightings of "mud plumes" as evidence of benthic feeding activity by gray whales.

Data collected during 90 complete or near-complete aerial surveys near the Odoptu seismic block were analyzed using quasi-likelihood multiple regression analyses (Yazvenko et al. 2002, 2007a,b) to determine if the seismic survey had demonstrable effects on gray whale distribution and feeding activity after allowance for potential confounding factors, e.g., sea state, visibility, glare, water depth, date, etc.

Vessel-based marine mammal observer program

A vessel-based MMO program, involving the seismic vessel Nordic Explorer and two support vessels, Rubin and Atlas, comprised a second element of the mitigation and monitoring program. Results from this program also helped determine the local distribution and abundance of western gray whales and other whales before, during, and after the Odoptu seismic survey, as suggested by the JNCC (Stone 2003), the HESS team (HESS 1999), and the Government of Australia guidelines (Environment Australia 2001).

The specific objectives of the vessel-based program during both the initial acoustic calibration trials and the subsequent seismic surveys included the following (Meier et al. 2002, 2007):

- Ensure that the Nordic Explorer's air guns did not operate if whales were seen within the designated buffer distances. This was achieved by detecting gray whales (and other whale species) within, or about to enter, the defined buffer zones, and initiating shutdowns when they were seen within or about to enter the buffer zone.

- Constantly observe any marine mammals visible from any of the three vessels. This included determining and recording the numbers of marine mammals (whales and seals) visible from the different vessels, and documenting their movements and activities.

Trained and experienced MMOs were present on the seismic ship and on two support ships. The lead MMO and a second observer were on the seismic ship and three MMOs were present on each support ship.
The MMOs on the seismic ship had the authority to shut down the air guns if whales were sighted within or approaching the relevant buffer distances.

During seismic operations in Area A (which were all during daylight with unobscured visibility), continuous observations were made by MMOs aboard the Nordic Explorer and the two support vessels. From 20 August onward, the Rubin moved along the landward edge of the $4-5 \mathrm{~km}$ buffer zone parallel to the seismic ship while shooting occurred in area A. This provided greatly enhanced visual coverage of the area directly inshore of the operating seismic vessel and removed ambiguity about the distance from the seismic vessel to marine mammals sighted in this area.

Seismic surveys in Area B maintained the same 4$5 \mathrm{~km}$ buffer zone for western gray whales and the same $1 \mathrm{~km}$ buffer zone for other whales. One or two MMOs were on continuous duty on each of the three vessels involved in the survey during daytime. During seismic operations in area $\mathrm{B}$ at night and during obscured visibility, MMOs were "on call", but were not on continuous duty.

Shore-based counts and behavior studies

Shore-based behavior monitoring of marine mammals is not specifically mentioned in any of the seismic survey guidelines (HESS 1999; Stone 2000; Environment Australia 2001). Nevertheless, in order to document possible changes in distribution and behavior of gray whales visible from shore, shore-based observations were implemented as part of the Odoptu seismic survey (Würsig et al. 2002; Gailey et al. 2007). However, due to logistics constraints, shore-based observations were not made before the seismic survey; observations were made only during and after the survey. Scan sampling counts, documentation of the behavior of focal animals, and theodolite tracking of gray whale movements followed procedures developed previously in the Piltun area (Würsig et al. 1999, 2000).

The overall objective was to examine smaller-scale distributional effects on feeding gray whales and to investigate whether their behavior was related to the presence or level of air gun sounds in the water. Univariate and multiple regression statistical analyses were used to look for possible differences in western gray whale behavior when seismic surveys were underway $v s$ when seismic surveys were not underway. 
The specific objectives of the 2001 behavior program were as follows (Gailey et al. 2007):

- Document gray whale behavior during and after the seismic program;

- Count the number of whales visible from shore using systematic scan sampling techniques;

- Conduct focal animal studies including theodolite (surveyor's telescope) observations of position, speed, orientation, and surface-respiration-dive cycles to correlate with results from other 2001 monitoring projects to evaluate responses to the seismic surveys.

Acoustic studies

Acoustic monitoring of received sound levels near whales during seismic surveys were not specifically mentioned in any of the seismic survey guidelines available in 2001 (HESS 1999; Stone 2000; Environment Australia 2001). However, the need for data on received sound levels during studies of disturbance had been emphasized elsewhere (e.g., Richardson et al. 1995, p. 57; NRC 2000). An acoustic monitoring program (Borisov et al. 2002; Rutenko et al. 2007) was designed and conducted as part of the Odoptu monitoring program. The goals of the acoustic program (Rutenko et al. 2007) were to establish appropriate buffer distances to protect whale feeding activity, to monitor levels of air gun sound received at the $20 \mathrm{~m}$ isobath just seaward of feeding whales, and to insure that received levels were $\leq 163 \mathrm{~dB}$ re $1 \mu \mathrm{Pa}$ (rms) while seismic operations were being conducted in Area B. The measured levels were also important in interpreting results from the related monitoring studies on western gray whale distribution, feeding activity, and behavior.

Acoustic calibration trials (2-16 August 2001) were conducted prior to the main seismic survey (17 August-9 September 2001) using the seismic ship Nordic Explorer (the ship to be used for the survey) and a team of acousticians. The trials determined the sound levels received via moored sonobuoys at various locations inshore of the Odoptu seismic survey block-primarily along the $20 \mathrm{~m}$ water depth contour, i.e., the outer margin of the gray whale feeding area. Some measurements also were taken in shallower water. Received sound levels were continuously relayed via radio telemetry to shore, with provisions to shut down the air guns if received levels along the $20 \mathrm{~m}$ isobath approached $163 \mathrm{~dB}$ re $1 \mu \mathrm{Pa}$ (rms), or if behavior of gray whales appeared to be affected by the air gun operations. The calibration trials determined that seismic pulses attenuated to $163 \mathrm{~dB}$ re $1 \mu \mathrm{Pa}$ (rms) about $7 \mathrm{~km}$ from the air gun array operating at full volume $\left(3,090 \mathrm{in}^{3} ; 28\right.$ air guns) and about $4 \mathrm{~km}$ from the array operating at about half volume (1,640 $\mathrm{in}^{3} ; 14$ air guns). This finding, and the subsequent decision to reduce the number of operating air guns (and array volume), were instrumental in achieving the $4 \mathrm{~km}$ feeding buffer distance.

During the actual seismic surveys, received sound levels were also continuously recorded and relayed via radio telemetry to a shore-based station, where they were monitored, recorded, and archived for subsequent analyses.

Passive acoustic monitoring (PAM) of marine mammals, i.e., detecting marine mammals by listening with hydrophones for their calls, is a potentially useful monitoring procedure mentioned in the JNCC, HESS, and Australian guidelines. For the Odoptu area, real-time passive acoustic monitoring of calling western gray whales was not implemented. Although summering gray whales do produce some sounds (Moore and Ljungblad 1984), we concluded that they do not vocalize frequently or strongly enough when feeding for PAM to be reliable or effective (M.E. Dahlheim and S.E. Moore, personal communication, National Marine Fisheries Service, Seattle, WA, USA).

Active acoustic monitoring (AAM), i.e., using active sonar, has been discussed and tested as a possible means to detect marine mammals near activities of concern. However, this technique was still under development in 2001 and thus was not implemented for the Odoptu seismic program.

\section{Effectiveness of the Odoptu mitigation and monitoring program}

All available guidelines and recommendations (through summer 2001) for mitigating impacts on marine mammals during seismic surveys were reviewed and evaluated, and all practicable measures that could have been effective in reducing adverse impacts of the Odoptu seismic program on western gray whales and other marine mammals were adopted. The monitoring studies were key elements in the overall mitigation strategy for the Odoptu seismic survey. The studies 
provided near real-time information necessary to implement mitigation measures during the course of the seismic survey. They also allowed adaptation of the mitigation program as new information became available during the seismic survey. The following discussion summarizes the effectiveness of the Odoptu monitoring studies; details are given in the cited companion papers on the individual studies (Gailey et al. 2007; Meier et al. 2007; Rutenko et al. 2007; Yazvenko et al. 2007a,b).

\section{Aerial monitoring}

Intensive and extensive aerial monitoring before, during, and after the Odoptu seismic surveys documented the distribution and abundance of feeding gray whales in and adjacent to the Odoptu seismic survey area and the Piltun feeding area (Yazvenko et al. 2007a,b). This information was transmitted to the seismic vessel on a near real-time basis and was used effectively to decide whether or not to conduct seismic surveys in some portions of the seismic block (Yazvenko et al. 2007a).

Statistical analyses showed no significant influence on gray whale feeding activity relative to seismic activity at $P=95 \%$ (Yazvenko et al. 2007b). Gray whales continued to be present and to feed in 2001 in the same general feeding areas used during 1999 and 2000 (Figs. 2 and 3), though about 5-10 gray whales apparently moved to a different part of the Piltun feeding area. Large-scale movements and other distributional shifts by western gray whales have been observed previously (Weller et al. 1999; Blokhin et al. 2003; Meier et al. 2007).

In some areas used for feeding by eastern gray whales, localized and temporary shifts in distribution have been shown to be associated with disturbance (Malme and Miles 1985; Malme et al. 1986, 1988). Other small- and large-scale changes in distribution have been linked to changes in prey distribution and availability, rather than to vessel activity (Bass 2000; Dunham and Duffus 2001, 2002; Meier 2003; Moore et al. 2003). The distribution and availability of gray whale prey in both the Piltun and newly discovered Offshore feeding areas were not known in 2001, but have subsequently been investigated. Results of these and other prey studies (Fadeev 2003, 2004, 2005, 2006) suggest that western gray whale distribution and abundance are correlated with prey distribution and abundance, as was to be expected. It is likely that feeding gray whales move around within their summer feeding grounds (Mate and Urban 2005) in response to natural factors, such as prey availability (Guerrero 1989; Dunham and Duffus 2001, 2002; Moore et al. 2003), and anthropogenic factors.

Vessel-based monitoring

Vessel-based monitoring of marine mammals by trained MMOs who had the authority to order the shut-down of the air guns was a key element in the Odoptu seismic mitigation and monitoring program (Meier et al. 2002, 2007).

MMOs on the seismic vessel and the two support vessels during daytime documented gray whale distribution within and near the 4-5 $\mathrm{km}$ buffer distance from the seismic vessel. Having a scout vessel move parallel to the seismic vessel but $4-5 \mathrm{~km}$ closer to the whale feeding area (shoreward) was an effective way to increase detection probability and minimize the chance of misjudging the position of a whale just inside the buffer distance. Five shutdowns of the air gun array were invoked for gray whales (Meier et al. 2002); one of these shutdowns occurred when a gray whale was within the $4 \mathrm{~km}$ buffer distance when first sighted (at $\sim 3,500 \mathrm{~m}$ in area A).

During the vessel-based monitoring study, a previously unknown gray whale feeding area was documented in September 2001 offshore from Chayvo Bay (Fig. 3) in waters 30-60 $\mathrm{m}$ deep (Maminov and Yakovlev 2002; Yazvenko et al. 2002). This discovery suggests that western gray whales are more widespread in their distribution and more flexible in their feeding behavior than previously reported. Current research is characterizing this new feeding area and is providing more information on the gray whales that feed there. Vessel-based surveys $150-180 \mathrm{~km}$ south of the Odoptu area in 2003 (SEIC 2003) further indicate that feeding western gray whales are distributed (although at lesser densities than near Piltun) over a wider region of the northeast Sakhalin coast than previously thought.

Shore-based counts and behavior studies

The goal of the shore-based study (Würsig et al. 2002; Gailey et al. 2007) was to investigate small-scale distributional and subtle behavioral effects of the seismic operation. Results of the behavior studies were 
compared to those from past studies (Würsig et al. 1999, 2000) of western gray whales near Piltun and elsewhere.

Scan sampling counts indicated that gray whales remained near the seismic survey area and continued to feed inshore of the Odoptu block throughout the seismic survey period. No significant correlations between gray whale abundance and seismic activity were found.

Univariate statistical comparisons of 2001 data during and after the seismic survey period indicated that parameters that differed were not correlated with seismic activity (Würsig et al. 2002; Gailey et al. 2007). Average values of most behavioral parameters studied during the Odoptu study were similar to those recorded in previous behavior studies in the Piltun area when no seismic surveys were occurring.

Multiple regression analyses indicated that, after taking environmental variables into account, 5 of 11 behavioral parameters, leg speed, re-orientation rate, distance offshore, mean duration between respirations, and dive time (Gailey et al. 2007), were statistically correlated with estimated seismic surveyrelated variables. The other six parameters, linearity, acceleration, mean direction, mean number of exhalations per minute at the surface, mean time at the surface, mean number of exhalations per minute during a surface-to-dive cycle, showed no such correlation (Gailey et al. 2007). During seismic operations, all behavioral parameters generally were within the natural range of variation attributable to environmental effects (Würsig et al. 2002; Gailey et al. 2007).

All measures of western gray whale behavior were significantly correlated with natural environmental variables, underscoring the necessity of allowing for such relationships when evaluating gray whale behavioral responses.

Univariate statistical analyses by other workers in the area during 2001 (Weller et al. 2002a, 2006) reported changes in western gray whale distribution during the 2001 seismic survey. However, these other studies did not consider the influences of natural environmental variables on gray whale behavior, which were shown to be significant in the present study.

Acoustic mitigation and monitoring

The goal of the acoustic program (Rutenko et al. 2007) was to establish buffer distances to protect whale feeding activity, and to measure levels of air gun sound received near or just offshore of feeding gray whales. Those measurements were important in interpreting results from the aerial, ship-based, and shore-based studies.

The acoustic measurements determined that the 4-5 km buffer zone and limiting the air gun array to 14 air gun elements with total volume 1,640 in ${ }^{3}$, were effective in limiting seismic sound levels near feeding western gray whales to $<163 \mathrm{~dB}$ re $1 \mu \mathrm{Pa}$ (rms), the upper limit selected a priori.

\section{Summary}

The Environmental Impact Assessment (EIA) that preceded the 2001 Odoptu seismic survey indicated that potential impacts on the western gray whale would require mitigation. Relevant guidelines and recommendations available at the time of the seismic survey (August-September 2001) were reviewed and evaluated to develop protocols for mitigating impacts on western gray whales and other marine mammals. All potentially effective and practicable measures were adopted. These included seasonal adjustments, modifications to the air gun array and survey area, implementation of shut-down and soft-start procedures, establishment of safety and disturbance buffers, and near real-time adjustments to operations based on monitoring results.

All four components of the monitoring work, i.e., aerial surveys, ship-based observers, acoustic measurements, and shore-based observations, provided data that were important both in real-time (for implementing mitigation) and in characterizing the overall effects. These studies complemented one another, and together provided sufficient information to reliably assess effects of the seismic program on western gray whales. Considerable new research on western gray whales and their acoustic environment has been conducted since 2001. New information from these studies will be useful in assessing impacts of other developments in the Sakhalin area and elsewhere.

Some western gray whales likely shifted southward within the Piltun feeding area during the Odoptu seismic survey (Yazvenko et al. 2007a; Weller et al. 2002a). Notwithstanding this shift, in the years since the Odoptu seismic survey (2002-present), there has been no evidence of a population-level or biologically 
significant (NRC 2005) impact of the 2001 Odoptu seismic survey on western gray whales. The number of "skinny" or emaciated whales noted in the population since 1999 declined after 2001, the number of calves produced annually reached record high numbers in 2003, a year when calf production would have been potentially affected by the seismic surveys in 2001, and there has been no contraction or reduction in the overall distribution or abundance of the whales in the Odoptu area after 2001 (Weller et al. 2004; Meier et al. 2007). In addition, recent estimates indicate the western gray whale population is growing at about 3\% annually (Cooke et al. 2006), and the size of the non-calf component of the western gray whale population is over $20 \%$ higher than reported during 2001 (122 vs <100; Weller et al. 2002c; Cooke et al. 2006).

Overall, the mitigation measures and monitoring programs implemented during the 2001 Odoptu seismic survey, which were among the most complex and extensive ever conducted for a marine mammal, were successful in reducing impacts on feeding western gray whales.

Acknowledgements Many people contributed to the Odoptu western gray whale mitigation and monitoring programs and the subsequent analyses and reporting. Special thanks to the team of vessel-based observers and aerial observers from the Pacific Research Center for Fisheries and Oceanography (TINRO-Center), Vladivostok, and Institute of Marine Biology (IBM), Far East Branch, Russian Academy of Sciences, Vladivostok; the team of acousticians from the Pacific Oceanological Institute (POI), Far East Branch, Russian Academy of Sciences, Vladivostok; and the team of land-based behavior specialists from Texas A\&M University (TAMUG), Galveston, Texas. We also thank Brien Reep, Phil Manella, Michael Allen, Oleg Shuranov, Alexei Kovalyov, and Dimitri Mayorov of Exxon Neftegas Limited, Yuzhno-Sakhalinsk, Sakhalin Island, Russia. Vostok Air Services provided reliable and safe helicopter and fixed-wing aircraft support. James Hall, ExxonMobil Upstream Research Company, Houston, Texas, provided useful editorial comments on this paper. Jim Eiler and Greg Manelick, Exxon Neftegas Limited, provided valuable logistics support at the Nogliki base camp and in YuzhnoSakhalinsk on Sakhalin Island. We also thank the captains and crews of the vessels Nordic Explorer, Rubin, and Atlas for their cooperation.

Various other Russian and North American scientists provided important advice and guidance during the various workshops, planning sessions, project reviews, and report reviews. For help with these tasks we thank Dorothy Baker, Sergei Balytsok, Yuri Blinov, Rolph Davis, Gennady Fedoseev, Lucia Ferreira, Julia Iazvenko, Jack Lawson, Charles Malme, Trent McDonald, Ryan Neilson, Keith Parker, Vladimir Radchenko, James Robinson, Vyacheslav Shuntov, Evgeny Sobolevsky,
Robin Tamasi, Valery Vladimirov, Peter Wainwright, and many others in Russia and North America. This study was sponsored by Exxon Neftegas Limited, Yuzhno-Sakhalinsk, Russia. Preparation of this paper was supported by both Exxon Neftegas Limited and Sakhalin Energy Investment Company, Yuzhno-Sakhalinsk, Russia.

\section{References}

Anonymous (2001). Krasnaya Kniga Rossiiskoi Federatsii. Zhivotnye. ["The Red Book of Russian Federation. Animals"]. Ast and Astrel, Balashikha, Aginskoe, 862 pp. [available at http://www.nature.ok.ru/redbook.htm].

Bass, J. (2000). Variations in gray whale feeding behavior in the presence of whale-watching vessels in Clayoquot Sound, 1993-1995. Ph.D. dissertation, University of Victoria, Victoria, BC, $156 \mathrm{pp}$.

Blokhin, S. A., Doroshenko, N. V., \& Marchenko, I. P. (2003). The abundance, distribution, and movement patterns of gray whales (Eschrichtius robustus) in coastal waters off the northeast Sakhalin Island coast in 2002 based on aerial survey data. Report by Pacific Research Center for Fisheries and Oceanography (TINRO-Center), Vladivostok, Russia, for Sakhalin Energy Investment Company and Exxon Neftegas Limited, Yuzhno-Sakhalinsk, Russia. [available at http://www.sakhalinenergy.com/en/library. asp? $\mathrm{p}=$ lib_sel_western_gray_whale $\& \mathrm{l}=$ whale recent research].

Blokhin, S. A., Maminov, M. K., Yazvenko, S. B., Doroshenko, N. V., \& Marchenko, I. P. (2006). History of finding western gray whales (Eschrichtius robustus) in the offshore area off the coast of Sakhalin Island and the 2001-2005 aerial surveys results. Abstract in Proceedings of the Conference on Marine Mammals of the Holarctic, 10-14 September 2006, St. Petersburg, Russia.

Blokhin, S. A., Vladimirov, V. L., Lagerev, S. I., \& Yazvenko. S. B. (2002). Abundance, distribution, and behavior of the gray whales (Eschrichtius robustus), based on aerial surveys off northeast coast of Sakhalin from July to November 2001. Report SC/O2/WGW03 to Western Gray Whale Technical Committee, International Whaling Commission, Ulsan, South Korea, 41 pp.

Borisov, S. V., Gritsenko, A. V., Jenkerson, M. R., Rutenko, A. N., \& Hodzevich, A. V. (2002). Evaluating and monitoring acoustic transmission from the Odoptu 3D seismic survey, 5 August-9 September, 2001. Environmental Monitoring and Assessment Report by V.I. Il'icev Pacific Oceanological Institute, Far East Branch, Russian Academy of Sciences, Vladivostok, Russia, and ExxonMobil Upstream Research Company, Houston, TX, for Exxon Neftegas Limited, Yuzhno-Sakhalinsk, Russia. Available from Exxon Neftegas Limited, c/o ExxonMobil Development Company, 17001 Northchase Drive \#466, Houston, TX 77060, Attn: Daniel Egging.

Cooke, J. G., Weller, D. W., Bradford, A. L., Burdin, A. M., \& Brownell, R. L., Jr. (2006). Population assessment of western gray whales in 2006. Paper SC/58/BRG30 presented to the Scientific Committee, International Whaling Commission. $10 \mathrm{pp}$. 
Dunham, J. S., \& Duffus, D. A. (2001). Foraging patterns of gray whales in central Clayoquot Sound, British Columbia. Marine Ecology Progress Series, 223, 299-310.

Dunham, J. S., \& Duffus, D. A. (2002). Diet of gray whales (Eschrichtius robustus) in Clayoquot Sound, British Columbia, Canada. Marine Mammal Science, 18, 419-437.

Environment Australia (2001). Guidelines on the application of the environment protection and biodiversity conservation act to interactions between offshore seismic operations and larger cetaceans. Attachment 6: Management guidelines for seismic vessels operating in Australian waters so as to avoid or minimize interference with whales and certain other larger cetaceans. Marine Species Section, Environment Australia, October 2001, Canberra. [available at http://www.deh.gov.au/epbc/assessmentsapprovals/guide lines/seismic/attachment6.html].

Fadeev, V. I. (2003). Benthos and prey studies in feeding grounds of the Okhotsk-Korean population of gray whales. Report on materials from field studies on the research vessel Nevelskoy in 2002'. Report by the Institute of Marine Biology, Far East Branch of Russian Academy of Sciences, Vladivostok, Russia, for Exxon Neftegas Limited and Sakhalin Energy Investment Company, Yuzhno-Sakhalinsk, Russia. 118 pp. [available at http:// www.sakhalinenergy.com/en/library.asp?p=lib_sel_wes tern_gray_whale\&l=whale_recent_research].

Fadeev, V. I. (2004). Benthos and prey studies in feeding grounds of the Okhotsk-Korean population of gray whales. Report on materials from field studies on the research vessel Nevelskoy in 2003. Report by the Institute of Marine Biology, Far East Branch of Russian Academy of Sciences, Vladivostok, Russia, for Exxon Neftegas Limited and Sakhalin Energy Investment Company, Yuzhno-Sakhalinsk, Russia. 191 pp. [available at http:// www.sakhalinenergy.com/en/library.asp?p=lib_sel_wes tern_gray_whale\&l=whale_recent_research].

Fadeev, V. I. (2005). Benthos and food supply studies in feeding areas of the Okhotsk-Korean gray whale population. Report based on results of field work aboard the research vessel Akademic Oparin. Report by the Institute of Marine Biology, Far East Branch of Russian Academy of Sciences, Vladivostok, Russia, for Exxon Neftegas Limited and Sakhalin Energy Investment Company, Yuzhno-Sakhalinsk, Russia. 157 pp. [available at http://www.sakhalinenergy.com/en/library. asp? $\mathrm{p}=$ lib_sel_western_gray_whale\&l=whale_recent research].

Fadeev, V. I. (2006). Status of benthos and food supplies in feeding areas of the Okhotsk-Korean gray whale population in 2005. Report by the Institute of Marine Biology, Far East Branch of Russian Academy of Sciences, Vladivostok, Russia, for Exxon Neftegas Limited and Sakhalin Energy Investment Company, Yuzhno-Sakhalinsk, Russia, 133 pp. [available at http://www.sakhalinenergy.com/en/library. asp?p=lib_sel_western_gray_whale\&l=whale_recent_ research].

Gailey, G., Würsig, B., \& McDonald, T. (2007). Abundance, behavior, and movement patterns of western gray whales in relation to a 3-D seismic survey, Norhteast Sakhalin Island, Russia. Environmental Monitoring and Assessment (this issue).
Gordon, J., Gillespie, D., Potter, J., Frantzis, A., Simmonds, M. P., Swift, R. et al. (2004). A review of the effects of seismic surveys on marine mammals. Marine Technology Society Journal, 37, 16-34.

Guerrero, J. A. (1989). Feeding behavior of gray whales in relation to patch dynamics of their benthic prey. M.Sc. Thesis, San Jose State University, San Jose, CA, 49 pp.

HESS (1999). High Energy Seismic Survey (HESS) review process and interim operational guidelines for marine surveys offshore Southern California. Report from High Energy Seismic Survey Team for California State Lands Commission and U.S. Minerals Management Service, Camarillo, California, 39 pp. [available at http://www. $\mathrm{mms}$. gov/omm/pacific/lease/fullhessrept.pdf].

Hilton-Taylor, C. (2000). 2000 IUCN red list of threatened species. IUCN/SSC, Gland, Switzerland, and Cambridge, United Kingdom.

Holling, C. S. (ed.) (1978). Adaptive environmental assessment and management. New York, NY: Wiley, 377 pp.

Malme, C. I., \& Miles, P. R. (1985). Behavioral responses of marine mammals (gray whales) to seismic discharges. In G. D. Greene, F. R. Engelhardt, \& R. J. Paterson (Eds.), Proceedings of a workshop on effects of explosives use in the marine environment, January 1985, Halifax, Nova Scotia, Technical Report 5, Canada Oil and Gas Lands Administration, Environmental Protection Branch, Ottawa, Ontario, 398 pp.

Malme, C. I., Miles, P. R., Clark, C. W., Tyack, P., \& Bird, J. E. (1983). Investigations of the potential effects of underwater noise from petroleum industry activities on migrating gray whale behavior. Report 5366 by Bolt Beranek \& Newman Inc., Cambridge, Massachusetts, for U.S. Minerals Management Service, Anchorage, Alaska, USA. Available as NTIS PB86-174174 from U.S. National Technical Information Service, 5285 Port Royal Road, Springfield, Virginia.

Malme, C. I., Miles, P. R., Clark, C. W., Tyack, P., \& Bird, J. E. (1984). Investigations of the potential effects of underwater noise from petroleum industry activities on migrating gray whale behavior/Phase II: January 1984 migration. Report 5586 by Bolt Beranek \& Newman Inc., Cambridge, Massachusetts, for U.S. Minerals Management Service, Anchorage, AK. Available as NTIS PB86-218377 from U.S. National Technical Information Service, 5285 Port Royal Road, Springfield, Virginia.

Malme, C. I., Würsig, B., Bird, J. E., \& Tyack, P. (1986). Behavioral responses of gray whales to industrial noise: Feeding observations and predictive modeling. Outer Continental Shelf Environmental Assessment Program, Final Report of Principal Investigators, 56, 393-600. Report 6265 (OCS Study MMS 88-0048) by Bolt Beranek \& Newman, Inc., Cambridge, MA, for National Oceanic and Atmospheric Administration, Anchorage, AK. Available as NTIS PB88-249008 from U.S. National Technical Information Service, 5285 Port Royal Road, Springfield, VA.

Malme, C. I., Würsig, B., Bird, J. E., \& Tyack, P. (1988). Observations of feeding gray whale responses to controlled industrial noise exposure. In W. M. Sackinger, M. O. Jeffries, J. L. Imm, \& S. D. Treacy (Eds.), Port and ocean engineering under arctic conditions, vol. II. Fairbanks, AK: Geophysical Institute, University of Alaska, 111 pp. 
Maminov, M. K., \& Yakovlev, Y. M. (2002). New data on the abundance and distribution of the gray whale on the northeastern Sakhalin shelf. Abstract in Proceedings of the Conference on Marine Mammals of the Holarctic, 11-13 September 2002, Baikal, Russia.

Mate, B., \& Urban, J. (2005). The spring northward migration and summer feeding of mother gray whales in the Eastern North Pacific. Abstract in Proceedings of the 16th Biennial Conference on Biology of Marine Mammals, 12-16 December 2005, San Diego, CA.

McCauley, R. D., Fewtrell, J., Duncan, A. J., Jenner, C., Jenner, M.-N., Penrose, J. D., et al. (2000a). Marine seismic surveys - a study of environmental implications. Australian Petroleum Production and Exploration Association Journal, 40, 692-708.

McCauley, R. D., Fewtrell, J., Duncan, A. J., Jenner, C., Jenner, M.-N., Penrose, J. D., et al. (2000b). Marine seismic surveys: analysis and propagation of air gun signals and effects of air gun exposure on humpback whales, sea turtles, fishes and squid. Project CMST 163, Report R9915 from Centre for Marine Science and Technology, Curtin University of Technology, Perth, Western Australia, Australia, 198 pp. [available at http://www.erin.gov.au/ epbc/assessmentsapprovals/guidelines/seismic/index. html\#conditions].

Meier, S. K. (2003). A multi-scale analysis of habitat use by gray whales (Eschrichtius robustus) in Clayoquot Sound, British Columbia, 1997-99. M.Sc. thesis, University of Victoria, Victoria, BC, $140 \mathrm{pp}$.

Meier, S. K., Lawson, J. W., Yazvenko, S. B., Perlov, A. S., Maminov, M. K., Johnson, S. R., et al. (2002). Vesselbased marine mammal monitoring during the $20013-\mathrm{D}$ seismic survey of the Odoptu block, northeast Sakhalin Island, Okhotsk Sea, Russia. Report by LGL Limited, Sidney, British Columbia, for Exxon Neftegas Limited, Yuzhno-Sakhalinsk, Russia, 38 p. Available from Exxon Neftegas Limited, c/o ExxonMobil Development Company, 17001 Northchase Drive \#466, Houston, TX 77060, Attn: Daniel Egging.

Meier, S. K., Yazvenko, S. B., Blokhin, S. A., Wainwright, P. W., Maminov, M. K., Yakovlev, Y. M., \& Newcomer, M. W. (2007). Distribution and abundance of western gray whales, northeast Sakhalin Island, Russia, 2001-2003. Environmental Monitoring and Assessment (this issue).

Miyashita, T., Nishiwaki, S., Vladimirov, V. A., \& Doroshenko, N. V. (2001). Cruise report on the minke whale sighting surveys in the Sea of Okhotsk, 2000. Report SC/53/RMP5 to the Scientific Committee, International Whaling Commission, Cambridge, $6 \mathrm{pp}$.

Moore, S. E., \& Clarke, J. T. (2002). Potential impact of offshore human activities on gray whales. Journal of Cetacean Research and Management, 4, 19-25.

Moore, S. E., \& Ljungblad, D. K. (1984). Gray whales in the Beaufort, Chukchi, and Bering seas: Distribution and sound production. In M. L. Jones, S. L. Swartz, \& S. Leatherwood (Eds.), The gray whale Eschrichtius robustus. Orlando, FL: Academic, $600 \mathrm{pp}$.

Moore, S. E., Grebmeier, J. M., \& Davies, J. R. (2003). Gray whale distribution relative to forage habitat in the northern Bering Sea: Current conditions and retrospective summary. Canadian Journal of Zoology, 81, 734-742.
NMFS (U.S. National Marine Fisheries Service) (1999). Taking and importing of marine mammals, Offshore seismic activities in the Beaufort Sea, Notice of issuance of an incidental harassment authorization. Federal Register, 64, 41384-41391.

NMFS (U.S. National Marine Fisheries Service) (2000). Small takes of marine mammals incidental to specified activities; Offshore seismic activities in the Beaufort Sea, Notice of receipt of application. Federal Register, 65, 21720-21726.

NRC (National Research Council) (1994). Low-frequency sound and marine mammals: Current knowledge and research needs. Washington, DC: National Academy Press.

NRC (National Research Council) (2000). Marine mammals and low frequency sound. Washington, DC: National Academy Press.

NRC (National Research Council) (2003). Ocean noise and marine mammals. Washington, DC: National Academy Press.

NRC (National Research Council) (2005). Marine mammal populations and ocean noise: Determining when noise causes biologically significant effects. Washington, DC: National Academy Press.

Quan, J., \& Calambokidis, J. (1999). Marine mammal observations and mitigation associated with USGS seismic surveys in the Southern California Bight in 1999. Report from Cascadia Research, Olympia, Washington, for U.S. Geological Survey, Menlo Park, California, 15 pp.

Richardson, W. J., Greene, C. R., Jr., Malme, C. I., \& Thomson, D. H. (1995). Marine mammals and noise. San Diego, CA: Academic, $576 \mathrm{pp}$.

Rutenko, A. N., Borisov, S. V., Gritsenko, A. V., \& Jenkerson, M. R. (2007). Calibrating and monitoring the mitigation zone and estimating acoustic transmission for the 2001 Odoptu 3D seismic survey. Environmental Monitoring and Assessment (this issue).

SEIC (Sakhalin Energy Investment Company) (2003). Seismic survey closure report: Report on observations of marine mammals from the seismic vessel Orient Explorer and RV Atlas for the period from July 28 til September 13, 2003. Report by Sakhalin Energy Investment Company, Yuzhno-Sakhalinsk, Russia. [available at http://www.sakhaline nergy.com/en/library.asp? p=lib_sel_western_gray_whale\&l=whale_recent_ research].

Sobolevsky, E. I. (2000). Marine mammal studies offshore northeast Sakhalin, 1999. Report by the Institute of Marine Biology, Far East Branch of Russian Academy of Sciences, Vladivostok, Russia, for Sakhalin Energy Investment Company, Yuzhno-Sakhalinsk, Russia, 149 pp. [available at http://www.sakhalinenergy.com/en/library. asp?p=lib_sel_western_gray_whale\&l=whale_recent_ research].

Sobolevsky, E. I. (2001). Marine mammal studies offshore northeast Sakhalin, 2000. Report by the Institute of Marine Biology, Far East Branch of Russian Academy of Sciences, Vladivostok, Russia, for Sakhalin Energy Investment Company, Yuzhno-Sakhalinsk, Russia, 199 pp. [available at http://www.sakhalinenergy.com/en/library. asp? $\mathrm{p}=$ lib_sel_western_gray_whale\&l=whale_recent_ research]. 
Stone, C. J. (1998). Cetacean observations during seismic surveys in 1997. JNCC Report 278, Joint Nature Conservation Committee, Aberdeen, Scotland. 55 pp. [available at http://www.jncc.gov.uk/page-2632].

Stone, C. J. (2000). Cetacean obserations during seismic surveys in 1998. JNCC Rep. 301, Joint Nature Conservation Committee, Aberdeen, Scotland. 62 pp. [available at http://www.jncc.gov.uk/page-2631].

Stone, C. J. (2003). The effects of seismic activity on marine mammals. JNCC Report No. 323, Joint Nature Conservation Committee, Peterborough, Scotland. [available at http://www.jncc.gov.uk/page-2337].

Urick, R. J. (1982). Sound propagation in the sea. Los Altos, CA: Peninsula Publications.

Weller, D. W., Burdin, A. M., Bradford, A. L., Ivashchenko, Y. V., Tsidulko, G. A., Lang, A. R., \& Brownell, R. L., Jr. (2004). Western gray whales off Sakhalin Island, Russia: A joint U.S.-Russian scientific investigation JulySeptember 2003. Report by National Marine Fisheries Service, National Oceanic and Atmospheric Administration, Southwest Fisheries Science Center, La Jolla, CA, Kamchatka Branch of Pacific Institute of Geography, Far East Division, Russian Academy of Sciences, Petropavlovsk, Kamchatka, Russia, and Alaska Sealife Center, Seward, AK. 41 pp.

Weller, D. W., Burdin, A. M., Bradford, A. L., Tsidulko, G. A., Ivashchenko, Y. V., \& Brownell, R. L., Jr. (2002b). Gray whales off Sakhalin Island, Russia: June-September 2001, A joint U.S.-Russian scientific investigation. Report by Texas A\&M University, Galveston, TX, Kamchatka Institute of Ecology and Nature Management, Russian Academy of Sciences, Petropavlovsk, Russia, and National Marine Fisheries Service, National Oceanic and Atmospheric Administration, Southwest Fisheries Science Center, La Jolla, CA, for Sakhalin Energy Investment Company Limited, Yuzhno-Sakhalinsk, Russia, 75 pp. [available at http://www.sakhalinenergy.com/en/library. asp?p=lib_sel_western_gray_whale\&l=whale_recent_ research].

Weller, D. W., Burdin, A. M., \& Brownell, R. L., Jr. (2002c). The western North Pacific gray whale: A review of past exploitation, current status, and potential threats. Journal of Cetacean Research and Management, 4, 7-12.

Weller, D. W., Ivashchenko, Y. V., Tsidulko, G. A., Burdin, A. M., \& Brownell, R. L., Jr. (2002a). Influence of seismic surveys on western gray whales off Sakhalin Island, Russia. Report $\mathrm{SC} / 54 / \mathrm{BRG} 14$ to the Scientific Committee, International Whaling Commission, Cambridge.

Weller, D. W., Tsidulko, G. A., Ivashchenko, Y. V., Burdin, A. M., \& Brownell, R. L., Jr. (2006). A re-evaluation of the influence of 2001 seismic surveys on western gray whales off Sakhalin Island, Russia. Report SC/58/E5 to the Scientific Committee, International Whaling Commission, Cambridge.

Weller, D. W., Burdin, A. M., Bradford, A. L., \& Würsig, B. G. (2001). Gray whales off Sakhalin Island, Russia: JuneSeptember 2000, a joint U.S.-Russian scientific investigation. Report by Texas A\&M University, Galveston, TX, and Kamchatka Institute of Ecology and Nature Management, Russian Academy of Sciences, Petropavlovsk, Russia, for Sakhalin Energy Investment Company Limited, Yuzhno-Sakhalinsk, Russia, 56 pp. [available at http://www.sakhalinenergy.com/en/library.asp?p=lib sel western gray whale\&l=whale recent research].

Weller, D. W., Würsig, B., Bradford, A. L., Burdin, A. M., Blokhin, S. A., Minakuchi, H., et al. (1999). Gray whales (Eschrichtius robustus) off Sakhalin Island, Russia: Seasonal and annual occurrence patterns. Marine Mammal Science, 15, 1208-1227.

Würsig, B., Gailey, G., McDonald, T., Nielson, R., OrtegaOrtiz, J., Wainwright, P., et al. (2002). Western gray whale occurrence patterns and behavior: Shore-based observations off Sakhalin Island, August-September 2001. Report by LGL Limited, Sidney, BC, for Exxon Neftegas Limited, Yuzhno-Sakhalinsk, Russia, 70 p. Available from Exxon Neftegas Limited, c/o ExxonMobil Development Company, 17001 Northchase Drive \#466, Houston, TX 77060, Attention: Daniel Egging.

Würsig, B., Weller, D. W., Burdin, A. M., Blokhin, S. A., Reeve, S. M., Bradford, A. L., et al. (1999). Gray whales summering off Sakhalin Island, Far East Russia: July-September 1997. A joint U.S.-Russian scientific investigation. Report by Texas A\&M University, Galveston, TX, and Kamchatka Institute of Ecology and Nature Management, Russian Academy of Sciences, Petropavlovsk, Russia, for Sakhalin Energy Investment Company Limited and Exxon Neftegas Limited, Yuzhno-Sakhalinsk, Russia, 103 pp. [available at http://www.sakhalinenergy.com/en/library.asp?p=lib_sel_ western_gray_whale\&l=whale_recent_research].

Würsig, B., Weller, D. W., Burdin, A. M., Reeve, S. M., Bradford, A. L., \& Blokhin, S. A. (2000). Gray whales summering off Sakhalin Island, Far East Russia: July-September 1998, A joint U.S.-Russian scientific investigation. Report by Texas A\&M University, Galveston, TX, and Kamchatka Institute of Ecology and Nature Management, Russian Academy of Sciences, Petropavlovsk, Russia, for Sakhalin Energy Investment Company Limited and Exxon Neftegas Limited, Yuzhno-Sakhalinsk, Russia, 133 pp. [available at http:// www.sakhalinenergy.com/en/library.asp? $p=1 i b \_s e 1$ wes tern_gray_whale\&l=whale_recent_research].

Würsig, B., Wells, R. A., \& Croll, D. A. (1986). Behavior of gray whales summering near St. Lawrence Island, Bering Sea. Canadian Journal of Zoology, 64, 611-621.

Yazvenko, S. B., McDonald, T. L., Blokhin, S. A., Johnson, S. R., Meier, S. K., Melton, H. R., et al. (2007a). Distribution and abundance of western gray whales during a seismic survey near Sakhalin Island, Russia. Environmental Monitoring and Assessment (this issue).

Yazvenko, S. B., McDonald, T. L., Blokhin, S. A., Johnson, S. R., Melton, H. R., Newcomer, M. W., et al. (2007b). Feeding activity of western gray whales during a seismic survey near Sakhalin Island, Russia. Environmental Monitoring and Assessment (this issue).

Yazvenko, S., McDonald, T. L., Meier, S., Blokhin, S., Johnson, S. R., Vladimirov, V., et al. (2002). Aerial marine mammal monitoring during the 2001 3-D seismic survey of the Odoptu block, northeast Sakhalin Island, Okhotsk Sea, Russia. Report by LGL Limited, Sidney, BC, for Exxon Neftegas Limited, Yuzhno-Sakhalinsk, Russia. 163 p. Available from Exxon Neftegas Limited, c/o ExxonMobil Development Company, 17001 Northchase Drive \#466, Houston, TX 77060, Attention: Daniel Egging. 